\title{
Reduction of vanadium(V) in a microbial fuel cell: V(IV) Migration and Electron Transfer Mechanism
}

\author{
Yuan Wang ${ }^{1}$, Yali Feng ${ }^{1}$, Haoran Li ${ }^{2, *}$, Chaorui Yang ${ }^{1}$, Juntong Shi ${ }^{3}$ \\ ${ }^{1}$ School of Civil and Resource Engineering, University of Science and Technology Beijing, Beijing \\ 100083, China; \\ ${ }^{2}$ State Key State Laboratory of Biochemical Engineering, Institute of Process Engineering, Chinese \\ Academy of Sciences, Beijing 100190, China; \\ ${ }^{3}$ Beijing National Day School, Beijing 100039, China; \\ *E-mail: hrli@ipe.ac.cn
}

doi: $10.20964 / 2018.11 .84$

Received: 5 July 2018 / Accepted: 27 August 2018 / Published: 1 October 2018

\begin{abstract}
The effects of vanadium on the microbial fuel cell performance, migration and distribution of V(IV) as well as electron transfer mechanism of single-chamber MFC were investigated by SEM, Fourier Transform Infrared Spectroscopy (FTIR), Cyclic Voltammetry (CV) and Electrochemical Impedance Spectroscopy (EIS). With anolyte vanadium concentration of $100 \mathrm{mg} / \mathrm{L}$, the shortest degradation cycle was $130.67 \mathrm{~h}$, while the degradation rate was $99.44 \%$. V(V) combined with hydroxyl and carboxyl groups to form $\mathrm{V}(\mathrm{IV})$ organic participates, part of which deposited on the anode surface, and the other part distributed in anolyte. $\mathrm{V}(\mathrm{V})$ around cathode was reduced to $\mathrm{V}(\mathrm{IV})$ receiving electrons from the anode, meanwhile $\mathrm{V}(\mathrm{V})$ in anolyte was reduced to $\mathrm{V}(\mathrm{IV})$ owing to the electrons transfer on membrane binding enzyme complex. $\mathrm{V}(\mathrm{V})$ participated in cathode reactions instead of oxygen, accelerating the synchronization and integrity of electrode reactions.
\end{abstract}

Keywords: microbial fuel cell; vanadium-containing wastewater; anode adsorption; membrane binding enzyme; V(IV) complex

\section{FULL TEXT}

(C) 2018 The Authors. Published by ESG (www.electrochemsci.org). This article is an open access article distributed under the terms and conditions of the Creative Commons Attribution license (http://creativecommons.org/licenses/by/4.0/). 